\begin{tabular}{|c|c|}
\hline \multicolumn{2}{|c|}{ International Journal of Trend in Scientific Research and Development (IJTSRD) } \\
\hline 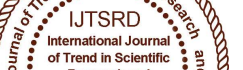 & International Open Access Journal | www.ijtsrd.com \\
\hline 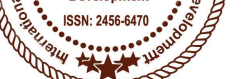 & ISSN No: 2456 - 6470 | Volume - 3 | Issue - 1 | Nov - Dec 2018 \\
\hline
\end{tabular}

\title{
Prevalence and Antibiogram of Bacteria Associated with Food Vending in Awka-South LGA, Anambra State, Nigeria
}

\author{
Egbuim, Timothy Chukwudiegwu ${ }^{1}$, Umeh, Sophina Ogonna ${ }^{1}$, Izuegbunam, Lilian Chinenye ${ }^{2}$ \\ ${ }^{1}$ Department of Applied Microbiology and Brewing, Faculty of Biosciences, \\ ${ }^{1}$ Nnamdi Azikiwe University, Awka, Anambra State, Nigeria \\ ${ }^{2}$ Department of Biology, College of Arts and Science, University of South Dakota, USA
}

\section{ABSTRACT}

Food vending is recently a booming part of the food industry and millions of people depend on it for their daily nutritional needs especially because of its easy accessibility. It has become an important public health issue due to widespread food-borne diseases which are leading cause of morbidity and mortality. This study is aimed at assessing the prevalence and antibiogram assay of bacteria associated with food vending in Awka-South LGA, Anambra State. The randomly selected towns for this study were three towns in Awka-South LGA in Anambra state namely Awka (State capital), Mbaukwu and Nise. Descriptive cross-sectional study and multistage sampling technique was adopted and sample size determined using a standard formula. Total of 65 food vendors were sampled. Sterile swab sticks were used to swab the palms, aprons, plates and spoons of the food vendors and the rinse method was used for bacteria isolation. Antibiotics sensitivity test of isolates was carried out using Kirby-Bauer disk diffusion method. The bacteria isolates from this study were $E$. coli (24.41\%), S. aureus $(21.60 \%)$, B. cereus $(9.39 \%)$, Pseudomonas aeruginosa (15.96\%), Serratia marcescens $(4.70 \%)$, Klebsiella pneumoniae (10.56\%) and Salmonella enterica (13.38\%). The bacterial isolates during the course of this study showed wide resistance to conventional antibiotics especially betalactams. The findings of this study therefore necessitate the need for sensitization of food vendors and appropriate measures should be established to monitor susceptibility patterns of microorganisms involved as this will help to avoid possible outbreaks.

Key words: Antibiogram, Food vendors, Bacteria, Antibiotic sensitivity

\section{INTRODUCTION:}

In developing countries like Nigeria in Western Africa, street food vending is very common because of their easy accessibility, low cost and convenient availability. The consumption of such food products have increased tremendously, becoming daily source of diet to millions of people in the country. Food is one of the most basic human needs and it is essential to sustain life (Agu, 2014). In as much as food is eaten primarily to sustain life, food should be nourishing, attractive and free from noxious substances such as poisonous chemicals, toxins and pathogenic microorganisms (McLauchlin and Little, 2007). Food if not carefully guarded against contaminations by the food vendors can do much harm to the consumer than the intended good.

The safety of street food has become one of the major concerns of public health and a focus for governments and scientists to raise public awareness (FAO, 2007; Mukhola, 2007). Food contamination is caused by many factors including traditional food processing methods, inappropriate holding temperatures, and poor personal hygiene of food handlers (Feglo and Sakyi, 2012). According to Monney et al. (2013), food vendors contaminate food by poor personal hygiene, cross-contaminating raw and processed food, as well as inadequate cooking and improper storage of food. Food is not supposed to cause harm to the consumer, but when it causes harm, a reverse of its intended good leads to food-borne diseases.

The world Health Organisation (WHO) (2010) stated that millions of people fall sick or die as a consequence of eating unsafe food. WHO (2015) estimates that as many as 600 million, or about one in every 10 people around the world is sickened by food- 
borne disease each year and 420, 000 people die as its result, including 125,000 children under the age of 5 years. Although epidemiological data on the incidence of food-borne diseases are inadequate, and the outbreak often not investigated; the recurrent incidences of food-borne illnesses with symptoms of gastro intestinal distress like diarrhea, vomiting, abdominal cramp and nausea has remained a major cause of mortality and morbidity in Nigeria (Nweze, 2010). According to Ihenkuronye (2012), more than 200, 000 persons die of food contamination annually in Nigeria, and these deaths are caused by contaminated foods through improper processing, preservation and service.

Assefa et al. (2015) reported that food handlers are carriers of potential food pathogens like Staphylococcus aureus, Klebsiella spp, E. coli, Enterobacter spp, Citrobacter spp, Serratia marcescens, Pseudomonas aeruginosa, Proteus spp, Providencia rettgeri and salmonella spp. Sharmila (2011) also reported that food vendors are carriers of food-borne pathogens like Escherichia coli, Salmonella, Shigella, Campylobacter and Staphylococcus aureus which they eventually transfer as food-borne hazards to the consumers.

Several food-borne diseases caused by bacterial pathogens are cured by using different class of conventional antibiotics already available but current development of resistance in almost all bacterial species to different classes of antibiotics poses a major threat to global healthcare. Several mechanisms are known to induce antibiotic resistance in bacteria, but the most common type of resistance develops and transmits horizontally via conjugation of a plasmid (Farzana et al., 2011). Likewise, evolution of multidrug-resistant (MDR) in bacterial strains, known as "superbugs" may create serious threat which results in resistance to several antibiotics (Alanis, 2005). With antibiotics resistance in microorganisms, the treatment of food-borne illnesses becomes difficult and if not handled with care leads to mortality. According to Farzana et al. (2011), the knowledge of susceptibility or resistance of bacterial species to various antibiotics helps in the effective treatment.

This study is aimed to reveal the prevalence of bacterial strains and their antibiotics susceptibility pattern in Awka-South LGA, Anambra State, Nigeria.

\section{MATERIALS AND METHODS}

\section{Study Area}

The study areas for this research were three selected towns in Awka-South LGA in Anambra State which includes Awka (State capital), Mbaukwu and Nise.

\section{Study Design}

In this study, Cross-sectional design was used.

\section{Study Population}

The target population was all food vendors who cooked and sold ready to eat foods within the selected study area and a total of 65 vendors were sampled.

\section{a. Inclusion Criteria}

The inclusion criteria were food vendors who sell cooked/prepared food on streets, markets, restaurants, fast-food joints and hawkers.

\section{b. Exclusion Criteria}

The exclusion criteria were food vendors who were not selling cooked foods, but snacks, fruits and vegetables.

\section{Ethical Approval and Consent to Participate}

Prior to data collection, permission was sought from the Ethical and Ethics Committee of Nnamdi Azikiwe University Teaching Hospital, Nnewi, Anambra State, Nigeria. Permission to conduct study in Awka-South LGA was equally sought from Federal Ministry of Health, Anambra State Directorate. At the individual level, Letter of Introduction and written informed consent was approved and used before food vendors were involved in the study.

\section{Sampling Technique}

This study employed multi-stage sampling technique which includes random, stratified and cluster techniques. The selected towns used in this study were randomly selected from the nine towns in AwkaSouth LGA, Anambra State, Nigeria. Each of the selected towns was considered a stratum, and the strata were clustered into groups pending on the availability and location of the food vendors. Proportionate sampling based on the number of food vendors in each cluster was done to get the number of respondents.

\section{Swab Collection}

A total of two hundred and twenty seven (227) swabs were aseptically collected from palms, plates, spoons and aprons of the food vendors ( 65 vendors) from the 
three selected towns. A sterile swab stick was dipped into normal saline and aseptically used to swab each of the surfaces of their palms, plates, spoons and aprons. After collection, the swab sticks were placed in sterile bags and conveyed to the Microbiology laboratory of Department of Applied Microbiology and Brewing, Nnamdi Azikiwe University, Awka for analysis.

\section{Source of Reagents and Materials}

Culture media used (Nutrient Agar, Blood Agar, MacConkey Agar, Mannitol Salt Agar, SalmonellaShigella Agar, Cetrimide Agar, Mueller-Hinton agar) were manufactured by Oxoid Ltd., UK. All reagents and materials used were of analytical standard.

\section{Preparation of Culture Media}

All culture media used were prepared according to the manufacturer's instructions. They were sterilized by autoclaving at $121^{\circ} \mathrm{C}, 15 \mathrm{psi}$ and for 15 minutes while Salmonella-Shigella agar was prepared by boiling in a water bath at temperature of $100^{\circ} \mathrm{C}$.

\section{Bacterial Isolation}

The rinse method as described by Lambrechts et al. (2014) was adopted. Each swab stick was aseptically rinsed into freshly prepared Nutrient Broth in test tubes $(5 \mathrm{ml}$ per test tube and plugged); the test tubes were incubated at $37^{\circ} \mathrm{C}$ for 24 hours for growth which is detected through turbidity. After incubation, a loopful of each broth was streaked progressively to obtain discrete colonies on appropriate culture media. The plates were incubated at $37^{\circ} \mathrm{C}$ for 24 hours and then observed at the end of the incubation for the kind of growth present on each agar. Discrete colonies were sub-cultured and pure cultures stored in slants of their respective media. The pure cultures were preserved at $4^{\circ} \mathrm{C}$ in a refrigerator.

\section{Identification and characterization of the Isolates}

The isolates were identified by Gram-staining, characterized biochemically and identified up to species level by performing standard tests.

\section{Antibiotics Susceptibility Testing and Analysis}

The susceptibility tests were performed using KirbyBauer disk diffusion method as recommended by Clinical Laboratory Standards Institute (CLSI, 2012) and National Committee for Clinical Laboratory Standards (NCCLS, 1997) using Mueller Hinton Agar. The bacterial strains were tested against the following Oxoid antibiotic sensitivity discs: Ciprofloxacin (CPR, $5 \mu \mathrm{g}$ ); Ceftazidime (CAZ, 30 $\mu \mathrm{g}$ );

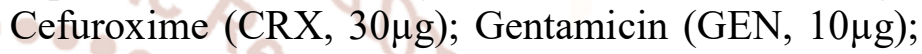

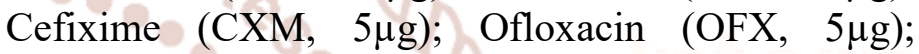
Amoxycillin/Clavulanic acid (AUG, 30 $\mu$ g); Nitrofurantoin (NIT, $5 \mu \mathrm{g}$ ). Inhibition Zone Diameter (IZD) was interpreted using standard charts, CLSI (2012) and Oxoid-CLSIFDA guidelines (2013).

\section{RESULT}

Potential Bacteria Isolated and Prevalence (\%)

Out of the 65 food vendors sampled and 227 samples collected, a total of 426 bacteria were isolated. Table 1 shows the morphological characteristics and biochemical identification of the bacteria isolates while the frequency of the isolates and their percentage prevalence are shown in Table 2. The isolates are potential bacteria implicated in food-borne disease outbreaks. 
International Journal of Trend in Scientific Research and Development (IJTSRD) ISSN: 2456-6470

Table 1: Morphological and Biochemical Characteristics of Bacteria Isolates

\begin{tabular}{|c|c|c|c|c|c|c|c|c|c|c|c|c|c|c|c|c|c|c|c|}
\hline $\mathbf{S}$ & 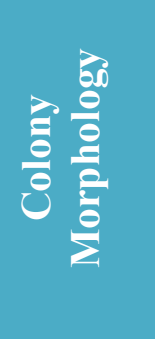 & 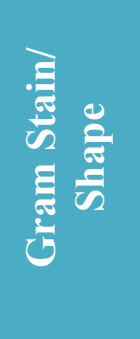 & 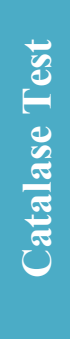 & 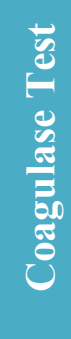 & 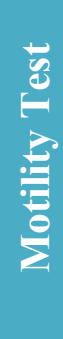 & 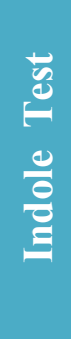 & 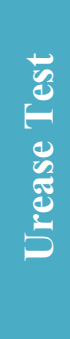 & $\begin{array}{l}\frac{1}{3} \\
\frac{5}{3} \\
\frac{1}{1}\end{array}$ & 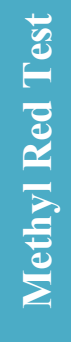 & 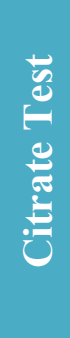 & 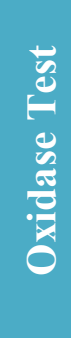 & 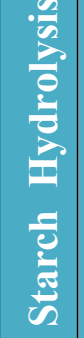 & 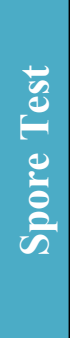 & 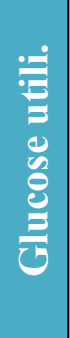 & 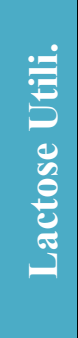 & 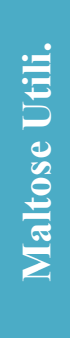 & | & 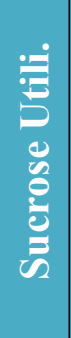 & Organism \\
\hline 1 & $\begin{array}{l}\text { Circular, } \\
\text { raised, } \\
\text { smooth } \\
\text { and } \\
\text { cream } \\
\text { Coloure } \\
\text { d. }\end{array}$ & $\begin{array}{l}+ \\
\text { Cocci } \\
\text { in } \\
\text { Cluster } \\
\mathrm{s}\end{array}$ & + & + & - & - & V & + & + & + & - & - & - & + & + & + & + & + & $\begin{array}{l}\text { Staphylococ } \\
\text { cus aureus }\end{array}$ \\
\hline 2 & $\begin{array}{l}\text { Oval, } \\
\text { Opaque } \\
\text { and } \\
\text { Pinkish }\end{array}$ & $\begin{array}{l}\text { Rods } \\
\end{array}$ & + & - & + & & - & - & + & - & - & - & & + & + & - & + & $\mathrm{V}$ & $\begin{array}{l}\text { Escherichia } \\
\text { coli }\end{array}$ \\
\hline 3 & $\begin{array}{l}\text { Black } \\
\text { centered } \\
\text { on SS } \\
\text { Agar }\end{array}$ & $\begin{array}{l}- \\
\text { Rods }\end{array}$ & & & & $\overline{1}$ & - & - & + & - & - & - & 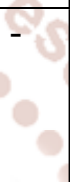 & + & - & + & + & - & $\begin{array}{l}\text { Salmonella } \\
\text { enterica }\end{array}$ \\
\hline 4 & $\begin{array}{l}\text { Bluish- } \\
\text { Green } \\
\text { on } \\
\text { Cetrimid } \\
\text { e Agar }\end{array}$ & $\begin{array}{l}- \\
\text { Rods }\end{array}$ & $t$ & - & + & 01 & - & & $\overline{0}$ & $t^{+}$ & + & 110 & $\bar{a}$ & $\begin{array}{l} \\
9 \\
9 \\
9\end{array}$ & 9 & & + & - & $\begin{array}{l}\text { Pseudomon } \\
\text { as } \\
\text { aeruginosa }\end{array}$ \\
\hline 5 & $\begin{array}{l}\text { Creamy, } \\
\text { Flat }\end{array}$ & $\begin{array}{l}+ \\
\text { Rods }\end{array}$ & + & 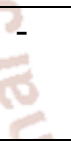 & + & - & - & $\begin{array}{l}+ \\
e y\end{array}$ & 10 & $\begin{array}{l}\mathrm{V} \\
\text { on }\end{array}$ & - & t & + & + & $\infty$ & + & - & + & $\begin{array}{l}\text { Bacillus } \\
\text { cereus }\end{array}$ \\
\hline 6 & $\begin{array}{l}\text { Pinkish- } \\
\text { red, } \\
\text { mucoid }\end{array}$ & $\begin{array}{l}\text { Rods } \\
\text { Rod }\end{array}$ & + & - & 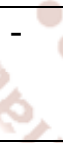 & - & + & + & 2 & $56=$ & & 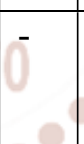 & - & & + & + & + & + & $\begin{array}{l}\text { Klebsiella } \\
\text { pneumoniae }\end{array}$ \\
\hline 7 & $\begin{array}{l}\text { Red } \\
\text { coloured } \\
\text { on } \\
\text { Nutrient } \\
\text { Agar }\end{array}$ & $\begin{array}{l}- \\
\text { Rods }\end{array}$ & + & & + & & - & + & - & $\begin{array}{l}+ \\
+ \\
\end{array}$ & $-c$ & 2 & & + & & + & + & + & $\begin{array}{l}\text { Serratia } \\
\text { marcescens }\end{array}$ \\
\hline
\end{tabular}

Key: $+=$ Positive, V-P $=$ Voges-Proskauer, V = varied

- = Negative, Utili. $=$ Utilization

Table 2: Frequency and Percentage Prevalence of the Bacteria Isolates

\begin{tabular}{|c|c|c|}
\hline Isolates & Frequency & Percentage prevalence (\%) \\
\hline Escherichia coli & 104 & 24.41 \\
\hline Staphylococcus aureus & 92 & 21.60 \\
\hline Bacillus cereus & 40 & 9.39 \\
\hline Pseudomonas aeruginosa & 68 & 15.96 \\
\hline Serratia marcescens & 20 & 4.70 \\
\hline Klebsiella pneumoniae & 45 & 10.56 \\
\hline Salmonella enterica & 57 & 13.38 \\
\hline
\end{tabular}

Total number of isolates $=426$ 
Antibiogram Assay of the Isolates

The bacteria isolates from this study showed a wide range of resistance to conventional antibiotics especially the beta-lactams. The results of their percentage (\%) antibiogram assay were presented in figures 1-7. The susceptibility profile of the isolates was graded as susceptible, intermediate and resistant.

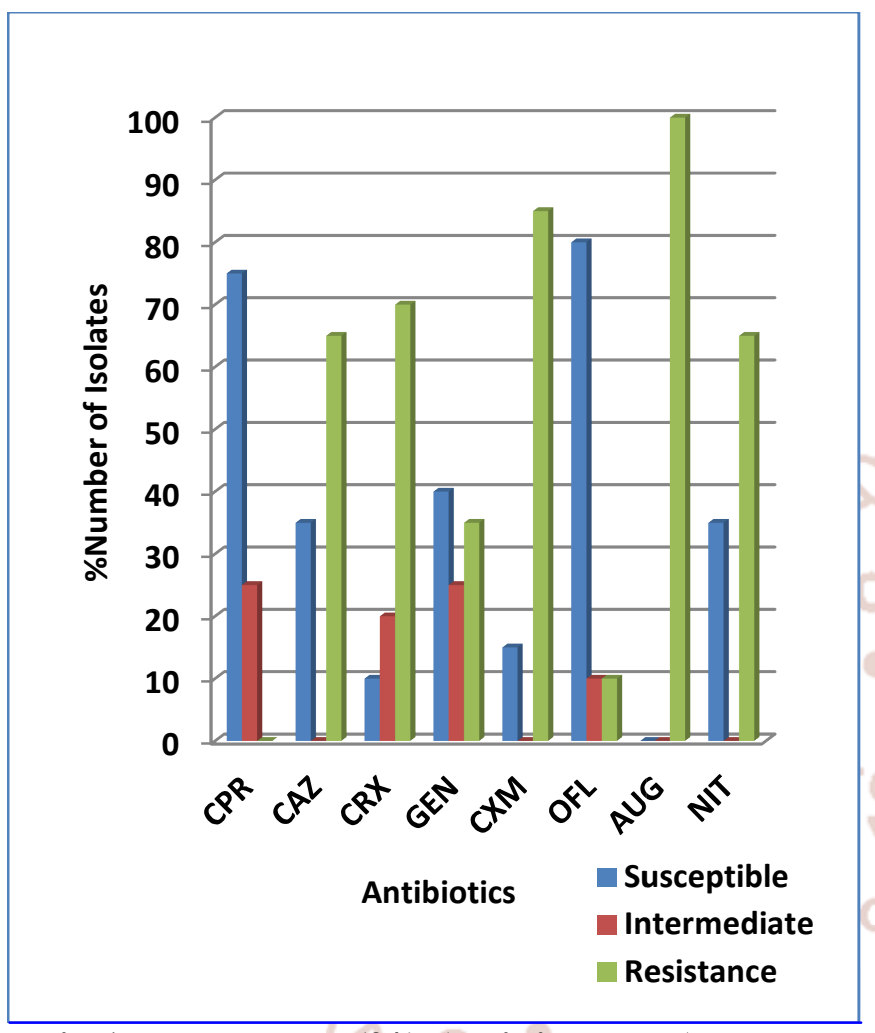

Fig 1: Percentage (\%) Antibiogram Assay on Escherichia coli isolates.

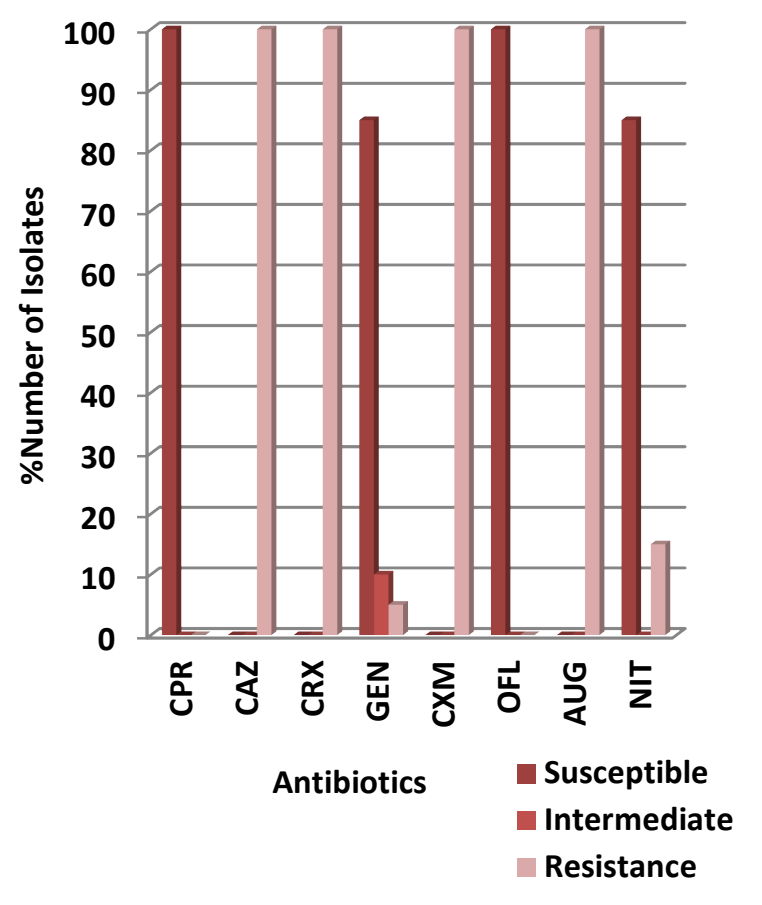

Fig 2: Percentage (\%) Antibiogram Assay on Staphylococcus aureus Isolates.

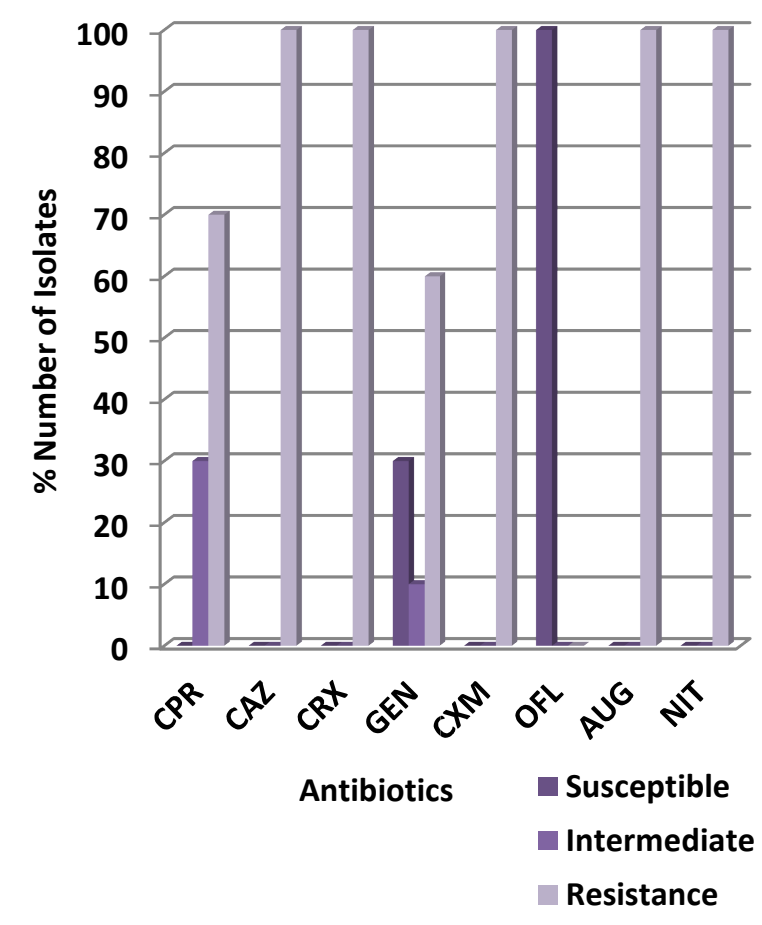

Fig 3: Percentage (\%) Antibiogram Assay on Bacillus cereus Isolates.

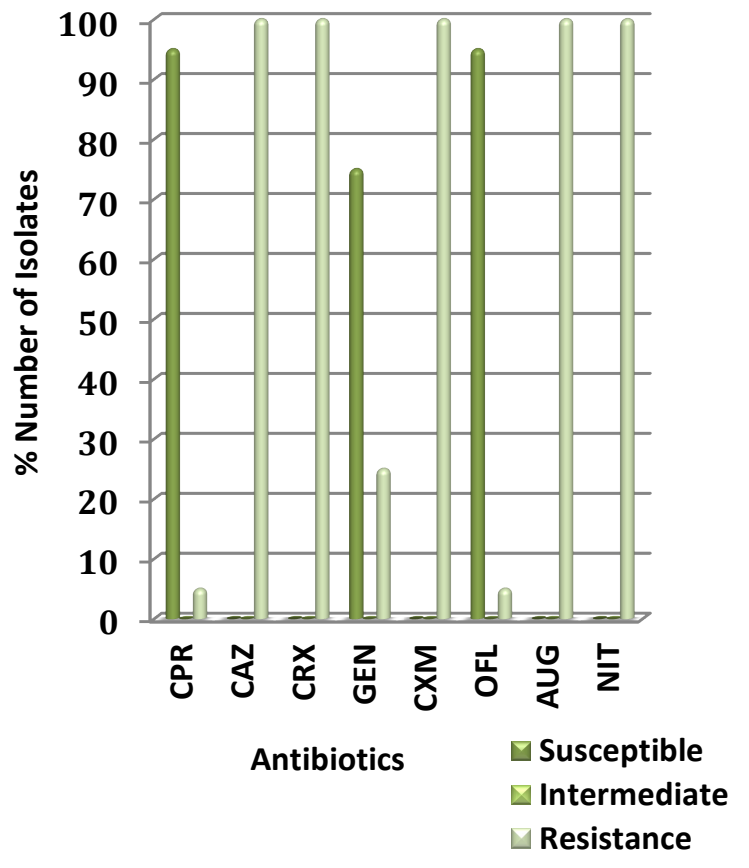

Fig 4: Percentage (\%) Antibiogram Assay on Pseudomonas aeruginosa Isolates. 


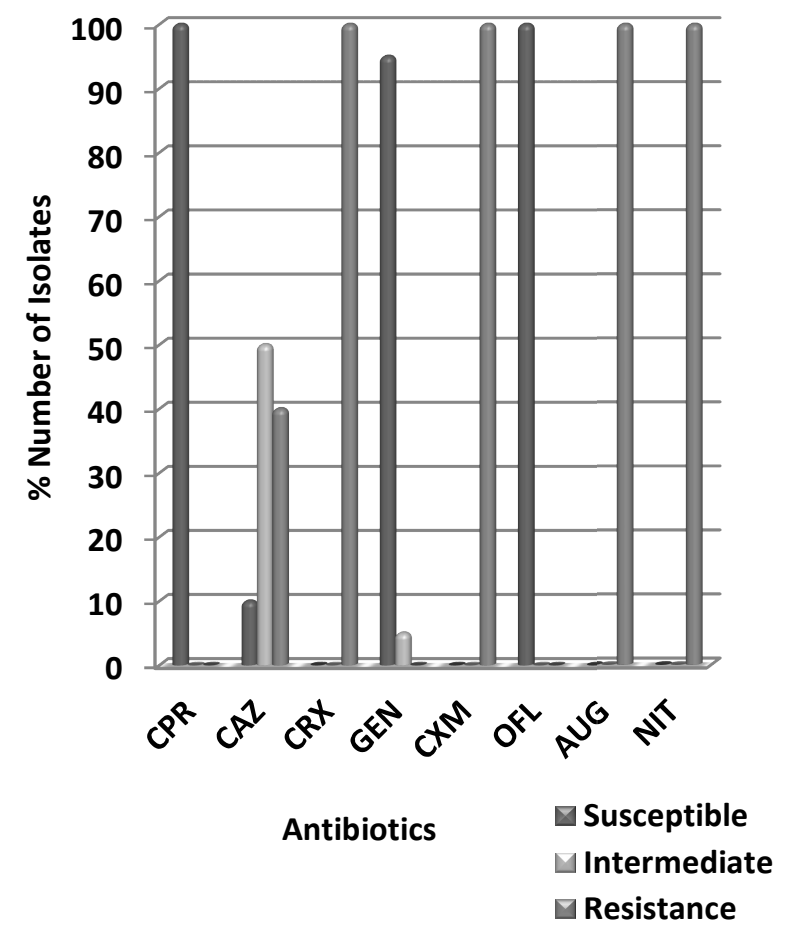

Fig 5: Percentage (\%) AntibiogramAssay on Serratia marcescens Isolates.
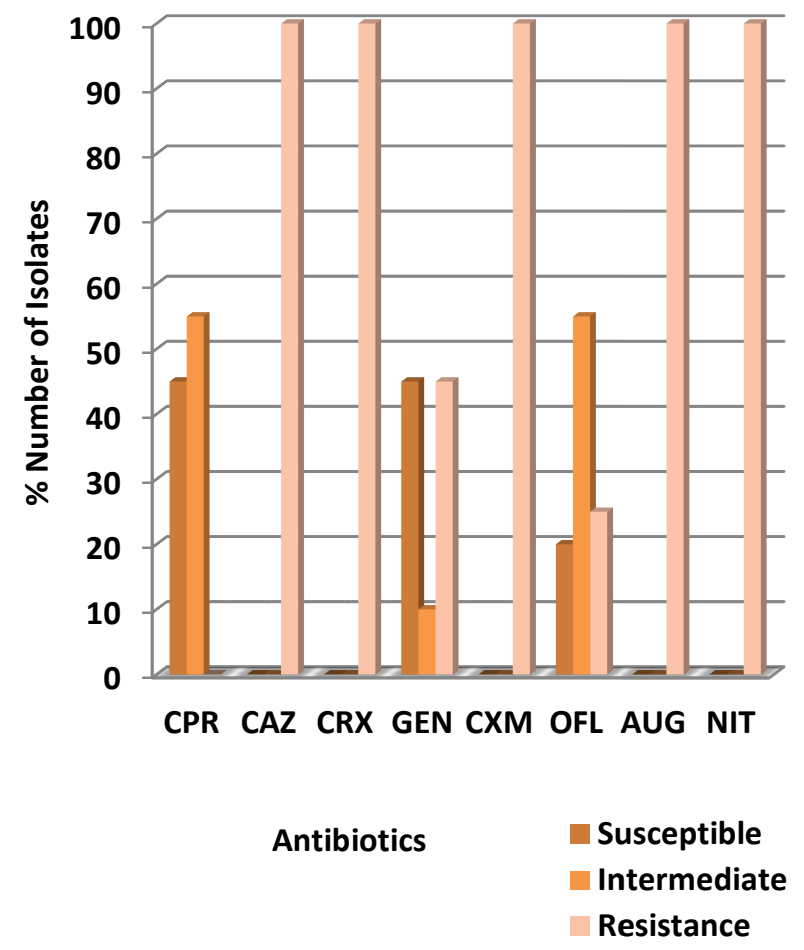

Fig 6: Percentage (\%) Antibiogram Assay on Klebsiella pneumoniae Isolates.

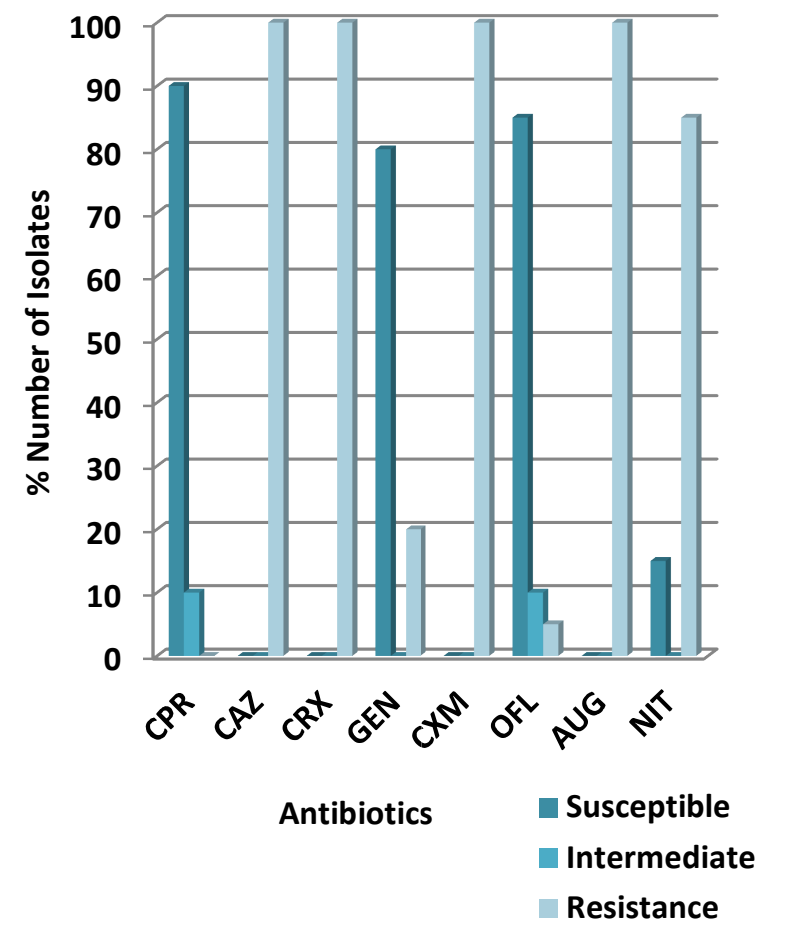

Fig 7: Percentage (\%) Antibiogram Assay on Salmonella enterica Isolates.

\section{DISCUSSION}

Food vending practices over the years has been a major cause of food-borne diseases globally especially in developing countries, where high incidence of food-borne diseases are recorded annually. The results of the study clearly indicates high level of unhygienic and sanitary practices among food vendors which concurs with Assefa et al. (2015) that food handlers are important vehicle for microorganisms, and their improper handling practices may cause food contamination and consequently food-borne diseases which pose a potential risk to public health.

The bacteria isolated in this study and their percentage prevalence had previously been implicated in foodborne disease outbreaks and they include; Escherichia coli (24.41\%), Staphylococcus aureus (21.60\%), Bacillus cereus (9.39\%), Pseudomonas aeruginosa (15.96\%), Serratia marcescens $(4.70 \%)$, Klebsiella pneumoniae $(10.56 \%)$ and Salmonella enterica (13.03\%). Similar types of microbial contaminants had been identified in previous studies in Benin City, Ogun State and Ondo State, Nigeria (Okareh and Erhahon, 2015; Bankole et al., 2009; Ibrahim et al., 2013). Furthermore, the isolates from this study also agrees with isolates from previous researches 
carried out in Gondar and Jimma, Ethiopia (Andargie, 2008; Assefa, et al., 2015); Saudi Arabia (Zaglool et al., 2011); Egypt (Fadel and Ismail, 2009); Puerto Rico (Dharod et al., 2009) and Brazil (Souza and Santos, 2009).

The microbial isolates from the study were accessed using antibiotics susceptibility assay (antibiogram) which was carried out to evaluate the activity of conventional antibiotics against the isolated bacteria; this is mainly to ascertain the nature of the microbes. The Escherichia coli isolates showed wide resistance to beta-lactam antibiotics i.e. $100 \%$ resistance to augmentin, $85 \%$ resistance to cefixime, $70 \%$ resistance to cefuroxime and $65 \%$ resistance ceftazidime. There was $75 \%$ and $80 \%$ susceptibility to ciprofloxacin and ofloxacin (fluoroquinolones), respectively. The antibiotics susceptibility profile of Escherichia coli isolates from this research agrees with similar findings by Abuchi et al. (2016) which recorded $100 \%$ resistance to beta-lactams (Ampicillin, ceftriaxone and cefuroxime) and $100 \%$ susceptibility to fluoroquinolones.

The Staphylococcus aureus isolates showed 100\% resistance to beta-lactam antibiotics especially penicillin and cephalosporins (augmentin, ceftazidime, cefuroxime and cefixime). There was $100 \%$ susceptibility to fluoroquinolones (ciprofloxacin and ofloxacin) and $85 \%$ susceptibility to nitrofurantoin and gentamicin, respectively. Consistent with the findings of this study, a similar study in India by Kuljinder and kahlon (2017) reported $70 \%$ and $80 \%$ susceptibility to ciprofloxacin and ofloxacin, respectively. The study also reported $80 \%$ susceptibility to gentamicin which is consistent with $85 \%$ susceptibility reported in this study. The Pseudomonas aeruginosa isolates showed 100\% resistance to beta-lactam antibiotics and nitrofurantoin, they were susceptible to fluorquinolones and gentamicin (75\%). Salmonella enterica isolates from this study were mostly resistant to beta-lactams and nitrofurnatoin, but were susceptible to fluoroquinolones and gentamicin. A similar study in Kenya by Sang et al. (2016) also reported high susceptibility to fluoroquinolones but in contrast to this study recorded susceptibility to the beta-lactam augumentin. Klebsiella pneumoniae isolates were $100 \%$ resistant to beta-lactams and nitrofurantoin, they were mainly intermediate at $55 \%$ to fluoroquinolones, and $45 \%$ susceptible to gentamicin. The Bacillus cereus isolates showed
$100 \%$ resistance to beta-lactams and nitrofurantoin. They showed $100 \%$ susceptibility to ofloxacin but $70 \%$ and $60 \%$ resistance to ciprofloxacin and gentamicin, respectively. Serratia marcescens isolates showed wide resistance to betalactams and nitrofuratoin, but they were highly susceptible to fluoroquinolones and gentamicin. The bacteria isolated during the course of this study showed wild resistance to beta-lactam antibiotics and this calls for public health attention.

\section{CONCLUSION}

Considering the high rate of resistance to antibiotics shown by the strains isolated from the food vendors, it can be concluded that there is wide spread of antibiotics resistance among microorganisms from different sources. This study emphasizes the need for intensive surveillance on isolates throughout the food production continuum to prevent food-borne diseases and also to detect emerging antimicrobial resistant microorganisms especially in developing countries like Nigeria.

\section{RECOMMENDATION}

Since microorganisms are ubiquitous and mostly opportunistic pathogens, this study recommends that proper hygiene and sanitary practices should be adopted by these vendors. Such hygiene practices can include sterilizing their wares (utensils, aprons) after daily vending activities. Also, use of antiseptic soaps to wash their hands often and regular use of hand sanitizers are recommended. Active antibiotics resistance surveillance system has to be developed in the country by the government as seen in developed countries. This will easily detect the presence of multidrug resistant contaminants in ready to eat foods and their selling environments. In cases of outbreaks and food-borne diseases, effective antibiotics should be used to treat diseases as this will help to avoid induced resistance in causative microbes.

\section{REFERENCES}

1. Abuchi, U., Gugu, T., Ugwu, B. C., Okezie, U., Unachukwu, C., Stanley, C. and Ugwu, C. M (2016). Incidence and Antibiotic susceptibility Pattern of Gram negative Bacteria isolated from Aprons of Meat vendors in Awka, Anambra Nigeria. World Journal of Pharmacy and Pharmaceutical Sciences, 5(4): 269-277.

2. Agu, N. M. (2014). Enhancing the Effectiveness of Poverty Reduction Initiative using Information 
International Journal of Trend in Scientific Research and Development (IJTSRD) ISSN: 2456-6470

Technology. Computing, Information Systems, Development Informatics \& Allied Research Journal, 5(1): 9-16.

3. Alanis, A. J. (2005). Resistance to Antibiotics: Are we in the Post-Antibiotic Era? Archives of Medical Research, 36: 697-705.

4. Andargie, G. (2008). Prevalence of Bacteria and Intestinal Parasites among Food-handlers in Gondar Town, Northwest Ethiopia. Journal of Health and Population Nutrition, 26: 451-455.

5. Assefa, T., Tasew, H., Wondafrash, B. and Beker, J. (2015). Assessment of Bacterial Hand Contamination and Associated Factors among Food Handlers Working in the Student Cafeterias of Jimma University Main Campus, Jimma, South West Ethiopia. Journal of Community Medicine and Health Education, 5: 345.

6. Bankole, M. O., Omemu, A. M. and Oladimeji, D. S. (2009). Microorganisms Associated with the Palms of Fast-Food Handlers in Abeokuta, Nigeria. Journal of National Science and Engineering Technology, 8(2): 77-85.

7. Clinical Laboratory Standard Institute (CLSI), (2012). Performance Standards for Antimicrobial Susceptibility Testing; Twenty-Second Informational Supplement. CLSI document M100S22, vol. 32, no. 3, Wayne, Pennsylvania, USA.

8. Dharod, J. M., Stefania, P. S., Bermúdez-Millán, A. and Venkitanarayanan, K. (2009). Bacterial Contamination of Hands Increases Risk of Cross contamination among Low-income Puerto Rican Meal Preparers. Journal of Nutritional Education Behaviour, 41: 389-397.

9. Fadel, H. M. and Ismail, J. (2009). Prevalence and Signifiance of Staphylococcus aureus and Enterobacteriaceae species in Selected Dairy Products and Handlers. International Journal of Dairy Science, 4: 100-108

10. FAO, (2007). School Kids and Street Food, Spotlight Magazine. Agriculture and Consumer Protection Department, United Nations. Retrieved 12th $\quad$ September 2017 from http://www.fao.org/AG/magazine/0702sp1.htm.

11. Farzana, K., Akram, R. M. and Mahmood, S. (2011). Prevalence and Antibiotics Susceptibility Patterns of some Bacterial Isolates from a Street
Vended Fruit Product. African Journal of Microbiology Research, 5(11): 1277-1284

12. Feglo, P. and Sakyi, K. (2012). Bacterial Contamination of Street Vending Food in Kumasi, Ghana. Journal of Medicine and Biomedical Science, 1: 1-8.

13. Ibrahim, T. A., Akenroye, O. M. and Osabiya, O. J. (2013). Bacteriological Analysis and Hygiene Level of Food Outlets within Rufus Giwa Polytechnic, Owo, Ondo State, Nigeria. Journal of Microbiology and Biotechnology, 2(4): 23472286.

14. Ihenkuronye, A. (2012). 200,000 People Die of Food Poison Annually in Nigeria. Premium Times Newspaper, Nigeria. Retrieved online on $24^{\text {th }}$ August, 2017 from http://www.premiumtimesng.com/news/96700200000-people-die-of-food-poison-annually-innigeria-prof-ihenkuronye.html.

15. Kuljinder, K. and Kahlon, R.S. (2017). Prevalence of Antimicrobial Resistance in Staphylococcus aureus Isolated from Ready to Eat Foods, Hand Swabs and Utensil Swabs of Street Vendors Selling Food on Wheels. International Journal of Current Microbiology and Applied Sciences, 6(5): 2424-2431.

16. Lambrechts, A. A., Human, I. S., Doughari, J. H. and Lues, J. R. (2014). Bacterial Contamination of the Hands of Food Handlers as Indicator of Hand Washing Efficacy in some Convenient Food Industries in South Africa. Pakistan Journal of Medical Sciences, 30(4): 755-758.

17. McLauchlin, J. and Little, C. (Eds.) (2007). Hobbs' Food Poisoning and Food Hygiene (3rd ed.). London: Edward Arnold publishers Limited. Pp. 32-34.

18. Monney, I., Agyei, D. and Owusu, W. (2013). Hygienic Practices among Food Vendors in Educational Institutions in Ghana: The Case of Konongo. Foods Journal, 2: 282-294.

19. Mukhola, M. S. (2007). Guidelines for an Environmental Education Training Programme for Street Food Vendors in Polokwane City. Retrieved online on 18th August, 2017 from http://etd.rau.ac.za/theses/submitted/etd03132007-140510/restricted/last.pdf.

20. National Committee for Clinical Laboratory Standards (NCCLS), (1997). Performance 
Standards for Antimicrobial Disk Susceptibility Tests $\left(6^{\text {th }}\right.$ Ed.). Approved Standard NCCLS Document M2-A6, vol. 17, no. 1, Wayne, Pennsylvania, USA.

21. Nweze, E. A. (2010). Aetiology of Diarrhea and Virulence Properties of Diarrheagenic Escherichia coli Among patients and Healthy Subjects in South East Nigeria. Journal of Health, population and Nutrition, 28(3): 245-252.

22. Okareh, O. T. and Erhahon, O. O. (2015). Microbiological Assessment of Food and HandSwabs Samples of School Food Vendors in Benin City, Nigeria. Food and Public Health Journal, 5(1): 23-28.

23. Oxoid-CLSIFDA guidelines, (2013). Retrieved $15^{\text {th }}$ March, 2017 from http://www.oxoid.com/pdf/uk/2013-CLSIFDAtable-update.pdf.

24. Sang, C., Odiwuor, S. and Oundo, J. (2016). Isolation, Identification and Antibiotic Susceptibility Profiles of Diarrheagenic Bacteria Associated with Food Handlers in Kericho Town, Kenya. Journal of Health, Medicine and Nursing, 6: 120-127.
25. Sharmila, R. (2011). Street Vended Food in Developing World: Hazard Analyses. Indian Journal of Microbiology, 51(1): 100-106.

26. Souza, P. A. and Santos, D. A. (2009). Microbiological Risk Factors Associated with Food Handlers in Elementary Schools From Brazil. Journal of Food Safety, 29: 424-429.

27. WHO, (2010). 10 Facts on Food Safety. Retrieved online on $17^{\text {th }}$ September, 2017 from http://www.who.int/features/factfiles/food_safety/ facts/en/ index.html

28. WHO, (2015). WHO's First Ever Global Estimates of Food-borne Diseases. Retrieved online on 7th May, 2017 from http://www.who.int/mediacentre/news/releases/20 15/foodborne- disease-estimates/en/.

29. Zaglool, D. A., Khodari, Y, A., Othman, R. and Farooq, M. U. (2011). Prevalence of Intestinal Parasites and Bacteria among Food Handlers in a Tertiary Care Hospital. Nigerian Medical Journal, 52: 266-270. 